\title{
Diffusion and success factors of mobile marketing
}

\author{
Arno Scharl $^{\mathrm{a}, *}$, Astrid Dickinger ${ }^{\mathrm{b}, 1}$, Jamie Murphy ${ }^{\mathrm{a}, 2}$ \\ ${ }^{\text {a }}$ UWA Business School, University of Western Australia, 35 Stirling Highway, Crawley, WA 6009, Australia \\ ${ }^{\mathrm{b}}$ Institute for Tourism and Leisure Studies, Vienna University of Economics and Business Administration, Augasse 2-6, A-1090, Vienna
}

Received 6 December 2003; received in revised form 1 May 2004; accepted 11 October 2004

Available online 30 October 2004

\begin{abstract}
Mobile marketing offers direct communication with consumers, anytime and anyplace. This paper reviews mobile marketing and then investigates the most successful form of mobile communication, short message services (SMS), via a quantitative content analysis of the Fortune Global $500 \mathrm{Web}$ sites and qualitative interviews with European experts. The content analysis explores the diffusion of SMS technology and sheds light on mobile marketing campaigns of large multinational organizations. Combining a literature review with results from the qualitative survey leads to a conceptual model of successful SMS advertising. The paper closes with future research avenues for this emerging marke ting tool.
\end{abstract}

(c) 2004 Elsevier B.V. All rights reserved.

Keywords: Mobile data services; Short Message Services (SMS); Mobile commerce; Online marketing; Success factors; Fortune Global 500 ; Web content analysis

\section{Introduction}

Innovation creates marketing opportunities and challenges. Mobile media, for example, transcend

\footnotetext{
${ }^{*}$ Corresponding author. Tel.: +61 86488 3908; fax: +61 8 64881055.

E-mail addresses: arno.scharl@uwa.edu.au (A. Scharl), astrid.dickinger@wu-wien.ac.at (A. Dickinger), jmurphy@ ecel.uwa.edu.au (J. Murphy).

${ }^{1}$ Tel.: +43131336 4487; fax: +4313171205

${ }^{2}$ Tel.: +61 86488 1979; fax: +61 864881055
}

traditional communication and support one-toone, many-to-many and mass communication $[1,2]$. Phones and personal digital assistants increase the availability, frequency and speed of communication. Yet the technology associated with these devices, which let marketers personally communicate with consumers, continues to evolve.

The most popular mobile application, referred to as text messaging in the UK or Short Message Service (SMS) in most other countries, attracted 580 million users who sent 431 billion messages in 2002 [3]. In the first quarter of 2004 users sent 135 billion SMS messages [4] and predictions are 
that 94.9 million mobile commerce users in 2003 will grow to 1.67 billion users by 2008 [5]. SMS will account for the bulk of mobile telephone companies' revenues from data services until 2006 [6,7]. This high diffusion of SMS facilitates analyzing usage behavior and hints at the commercial potential of future communication services. Multimedia Messaging Services (MMS), for example, will build on the success of SMS [8] but allow for richer content based on similar asynchronous, digital and interactive communication.

Studying interactive mobile services such as SMS and MMS suggests drawing upon theories in marketing, consumer behavior, psychology and adoption to investigate their organizational and personal use [1,9-11]. But research on mobile marketing via SMS is scarce [12-14]. This paper uses two complementary techniques - quantitative Web content analysis and qualitative interviews to help fill that void and address four research questions. What mobile marketing insights does Web coverage by the world's leading companies provide? What do European experts conclude about mobile advertising via SMS? What model helps explain effective mobile advertising? Finally, what future research avenues merit exploration?

This paper opens with a quantitative analysis of mobile marketing terminology used on the Fortune Global $500 \mathrm{Web}$ sites. After this snapshot of mobile marketing, the subsequent section presents the second major contribution of the paper. Qualitative interviews with European experts on a subset of mobile marketing, SMS, yield proposed success factors and a conceptual model of mobile advertising. The paper closes with an analysis of the findings and their implications, as well as future directions for research.

\section{Corporate Web sites reflecting mobile marketing trends}

Consumer trends and increased Internet usage shape the evolution of mobile marketing. Corporate Web sites often serve as the primary point of contact, asking consumers for permission to receive SMS and participate in campaigns. Past research has shown that personal innovativeness increases the rate of adoption of mobile services [15]. Given their familiarity with interactive technologies, acceptance of mobile marketing campaigns should be higher among Web users than among the overall population. Furthermore, text messaging is an additional communication channel for marketing campaigns that integrates easily into the media mix [16]. Several software packages combine SMS and Web-based channels - e.g., Flytxt's FXTrinity, Mindmatic's Wireless Interactive Box, UCP's Mobile Media Platform, and the Chordiant Marketing Director [17] illustrated in Fig. 1.

The growing interest in Web services [18], remote resources accessible via the Internet, contributes to this convergence of SMS and Web channels. Sharing information across applications and devices regardless of hardware, operating systems or software, Web services bridge traditional computing and mobile networks [19]. Examples of Web services range from simple phone directories or postal code lookup services to package tracking, stock quotes, and Microsoft's Passport initiative (www.passport.net) [20]. Investments by the software industry to lay the foundation for Web services should fuel the diffusion of mobile technology.

\subsection{Quantitative research methodology}

To investigate the diffusion of mobile marketing among major corporations, this research studied the Web sites of the world's leading companies according to the 2002 edition of the Fortune Global 500 (www.fortune.com). Researchers have used Fortune Magazine's rankings of top companies in disciplines such as business ethics [21], health care [22], human resources [23], quality management [24], international business [25], and Web site evaluation [26,27].

Previous research has built a foundation for analyzing the structure and content of large samples of Web-based information systems [28,29]. Textual data gathered from Web sites contain valuable information about industry trends and competitive strategies. Approaches to analyzing and visualizing such data stem from corpus linguistics, textual statistics, discourse analysis, computer science, Web engineering and socioeconomic survey analysis [30,31]. 


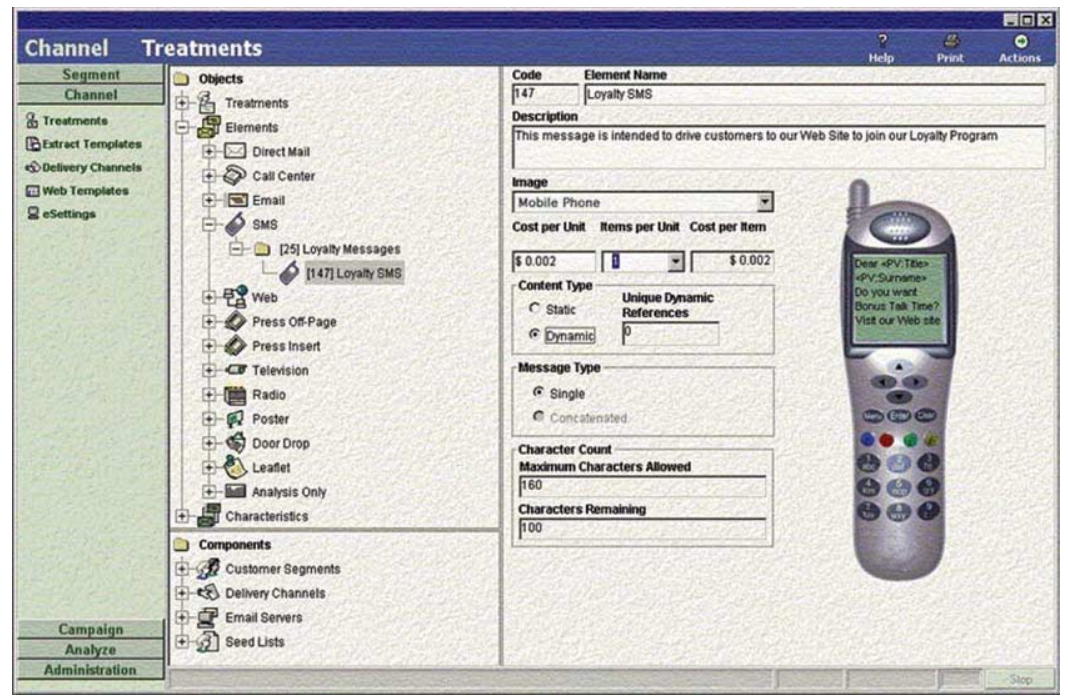

Fig. 1. User interface of the Chordiant 5 Mobile Marketing Director.

For this study, a software tool processed the corporation's home page and then followed the site's hierarchical structure until amassing 10 megabytes of visible (raw text including headings, menus, and link descriptions) and invisible text (embedded markup tags, scripting elements, and so forth). The markup code and embedded scripts provided a hierarchical document tree to guide the mirroring. After removing all the tags and scripts from the documents, the robot then wrote the visible text into a single file for processing. As a rule of thumb, ten megabytes of visible and invisible text yielded three to five megabytes of plain text. The 10 megabyte limit helps manage available storage space and compare sites of heterogeneous size $[28,32]$.

The March 2003 study omitted 84 of the Fortune Global 500 sites for several reasons: discontinued sites due to mergers or acquisitions, non-existent or inaccessible addresses, outliers with insufficient content, and sites that caused technical problems during the data gathering process. Nevertheless, the software tool yielded almost four gigabytes of textual data $(290,000$ documents comprising 70 million words). Of the remaining 416 sites, almost half $(43 \%)$ belonged to companies headquartered in the Unites States, followed by Europe and Asia at $31 \%$ and $24 \%$, respectively.
The predominant industries were finance and insurance $(24 \%)$, resources $(9 \%)$, and food, beverage and tobacco $(8 \%)$.

\subsubsection{Language detection}

A sample as culturally heterogeneous as the Fortune Global 500 requires effective language detection. Several techniques tackle this issue, usually based on trigrams and common short words [33]. Trigrams compare a document's frequency of three-letter sequences with a particular language's distribution of these same three-letter sequences. Similarly, common short words such as determiners, conjunctions and prepositions help discern a language. As both methods produce comparable results for chunks of text larger than ten words [34], this research used the computationally lighter short word technique.

The language detection covered five Indo-European languages (English, Spanish, German, French, and Italian), representing the native languages for $58 \%$ of the global online population [35]. The algorithm classified content within each document. Use of English (46\%) among the 416 sites dwarfed content in the four other languages: French (18\%), German (14\%), Italian (14\%), and Spanish (5\%). 


\subsubsection{Frequency distribution by region}

After assigning languages to each document, statistical tests uncovered regional differences in occurrences of the following groups of mobile marketing terms:

- SMS \{SMS, text messaging, short message service, short messaging service\}.

- Mobile Phone \{mobile phone, mobile telephone, cell phone, cellular, handy\}.

- Mobile Commerce \{M-Commerce, mCommerce, mobile commerce\}.

Over half $(59 \%)$ of the 416 sites contained at least one mobile phone term. SMS and mobile commerce terms were less popular at $20 \%$ and $5 \%$, respectively, yet these same terms seemed to transcend language barriers and occurred on sites that contained little or no English content. As with other interactive technologies, mobile usage differs by continent and culture [36,37]. The distribution of mobile terms in Fig. 2 reflects the availability and pervasive role of mobile technologies in European and Asian every-day life.

Given the violation of the assumptions of oneway analysis of variance (normal distribution for each population, variance homogeneity), a nonparametric Kruskal-Wallis test indicated significant regional differences for the first two groups of terms: $S M S \chi^{2}(2, N=407)=12.977, p=0.002$, and Mobile Phone $\chi^{2}(2, N=407)=11.747$, $p=0.003$. Differences for Mobile Commerce were not significant at $\chi^{2}(2, N=407)=; 1.224$, $p=0.542$. These results support the idea that affordability enhances SMS acceptance [38]. Text messaging costs are lower in Asia compared to Europe or the United States [39]. SMS has been most successful in Japan, with an average of 119 monthly messages per user in 2001 [39]. Europe also has strong growth in text messaging [40]. In the third quarter of 2003 the average European user exchanged 35 messages per month, resulting in 15 billion monthly SMS messages [7].

Compared to Western Europe and parts of Asia, the United States lacks a unified national infrastructure, which hinders mobile phone users from exchanging SMS messages between networks. The low frequency of SMS terms in North America documents the region's fragmented market and slow SMS adoption [7,41]. As only 12\% of mobile phone users in the United States sent text messages in 2001, many companies perceived the technology as unsuccessful [42]. Acceptance improved by 2003 , with more than one in four mobile phones users sending or receiving at least one message daily [43]. Nevertheless, usage in the United States remains low compared to Europe and Asia $[7,42,43]$.

\subsubsection{Frequency distribution by industry}

Comparing the Web site data across industries illustrates the organizational diffusion of mobile

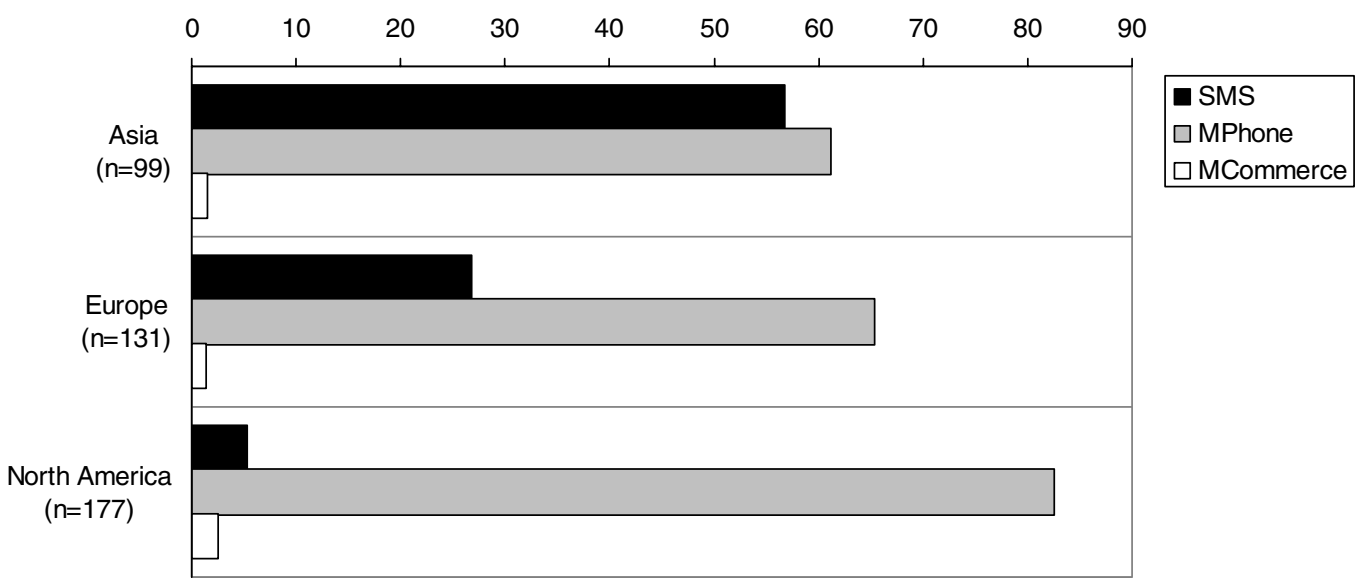

Fig. 2. Regional popularity of 'SMS', 'Mobile Phone', and 'Mobile Commerce' (occurrences per million tokens; sample size of other regions $\leqslant 5)$. 
technologies. Fig. 3 presents the cumulative term frequencies by industry, as of March 2003. Besides their popularity with telecommunications and electronics companies, SMS and mobile commerce terms showed high frequencies in the financial, insurance and automotive sectors.

Already in 1996, Singaporeans sent SMS messages to inform taxi drivers about clients in their vicinity. If someone ordered a taxi, a Global Positioning System (GPS) in the mobile phone identi- fied the user's location and alerted drivers via SMS. If the closest driver refused, the system automatically redirected the SMS to the second closest taxi [44]. Prototype developments in the automotive industry focus on traffic alerts and early-warnings to avoid potential dangers [45]. If a driver (or a future smart car with the ability to detect fog, for example) submits a warning, an SMS message warns other drivers with mobile devices approaching the specified location.

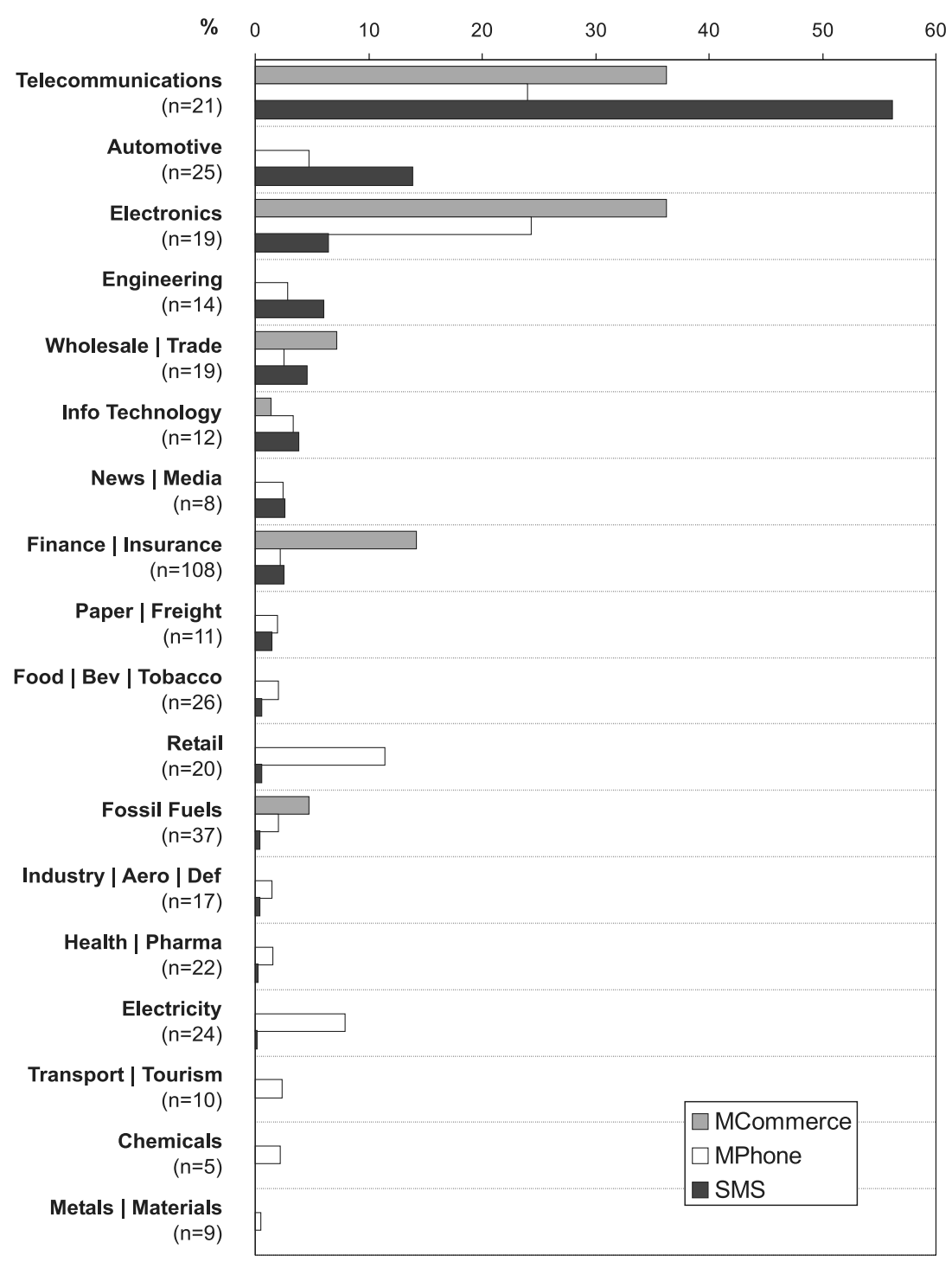

Fig. 3. Relative frequencies of 'SMS', 'Mobile Phone', and 'Mobile Commerce' terms by industry. 
The development of mobile payment systems helps explain [46] the affinity of finance and insurance towards mobile commerce. Kannan et al. [46] describe how mobile commerce supplements cash and credit cards - e.g., paying via SMS messages or using electronic wallets linked to pre- or postpaid services. Contactless smart cards facilitate transactions [47] by automatically connecting with public terminals while the customer is in range. Instead of SMS, proximity transactions typically rely on infrared signals, radio transmission or Bluetooth [47].

Three pilot projects illustrate the feasibility of mobile payment. Austrians use PayBox to obtain parking permits or tickets for cultural events [48], Scandinavians purchase Coca Cola through "Dial-a-Coke" vending machines [49], and South Koreans substitute train tickets with their mobile phones when passing through electronic turnstiles [47].

\subsubsection{Correspondence analysis}

The previous descriptions outline important topics by region and industry, but do not reflect semantic relationships. Correspondence analysis addresses this shortcoming by identifying lowdimensional sub-spaces in a joint plot known as a perceptual map [50]. The perceptual map of Fig. 4 compares relative term frequencies among the Fortune Global 500 industries. The rectangular and circular markers denote industries and mobile marketing concepts, respectively. In addition to the SMS, mobile phone, and mobile commerce categories described previously, Fig. 4 shows the relative importance of the following mobile technologies: Global System for Mobile Communications (GSM), General Packet Radio Service (GPRS), I-mode, Multimedia Messaging Service (MMS), Universal Mobile Telecommunications Systems (UMTS), Voicemail (VMail), Wireless Application Protocol (WAP), and Wireless Markup Language (WML).

The diagram's vertical dimension reflects industry orientation towards information and communications technologies. Information technology and electronics companies frequently mention wireless networks and services. Companies in other sectors focus on terms such as mobile phones and text messaging, reflecting widespread acceptance across industries.

Most terms referring to telecommunications infrastructure (GSM, GPRS, UMTS) and services (WAP, MMS) aggregate in the right of the diagram, near the telecommunications sector. For other industries, infrastructure-related terms seem less relevant. For the services, this aggregation suggests that industries have either failed to embrace these services (WAP), or that their development is in its infancy (MMS). Envisioned as a standard for small portable devices, WAP struggles for market share due to slow connection speeds and high service costs [15].

Based on the Web presence of Fortune Global 500 companies, this section identified regional and industry differences in the diffusion of mobile technologies. The findings underpin the leading position of Asian markets with regard to the adoption rate of mobile services. Sending tailored advertising messages via mobile services extends an organization's portfolio of communication channels. The next section focuses on using mobile media to deliver such messages.

\section{A conceptual model of SMS advertising}

The American Marketing Association defines marketing management as "planning and executing the conception, pricing, promotion and distribution of goods, services, and ideas to create exchanges that satisfy individual and organizational goals" [51, p. 1]. This definition implies temporal and spatial separation of buyers and sellers. The ubiquity of mobile devices, however, extends traditional marketing's time-space paradigm [52], and amplifies the importance of location, time, and personalization.

A key component of mobile marketing communication is advertising, either in a push or pull mode. After obtaining the consumer's permission, push advertising sends relevant but not explicitly requested text messages. Quah and Lim [53] argue that the push model will dominate mobile advertising since it saves consumers' time and money compared to browsing content. Pull advertising, by contrast, adds messages - often free information 


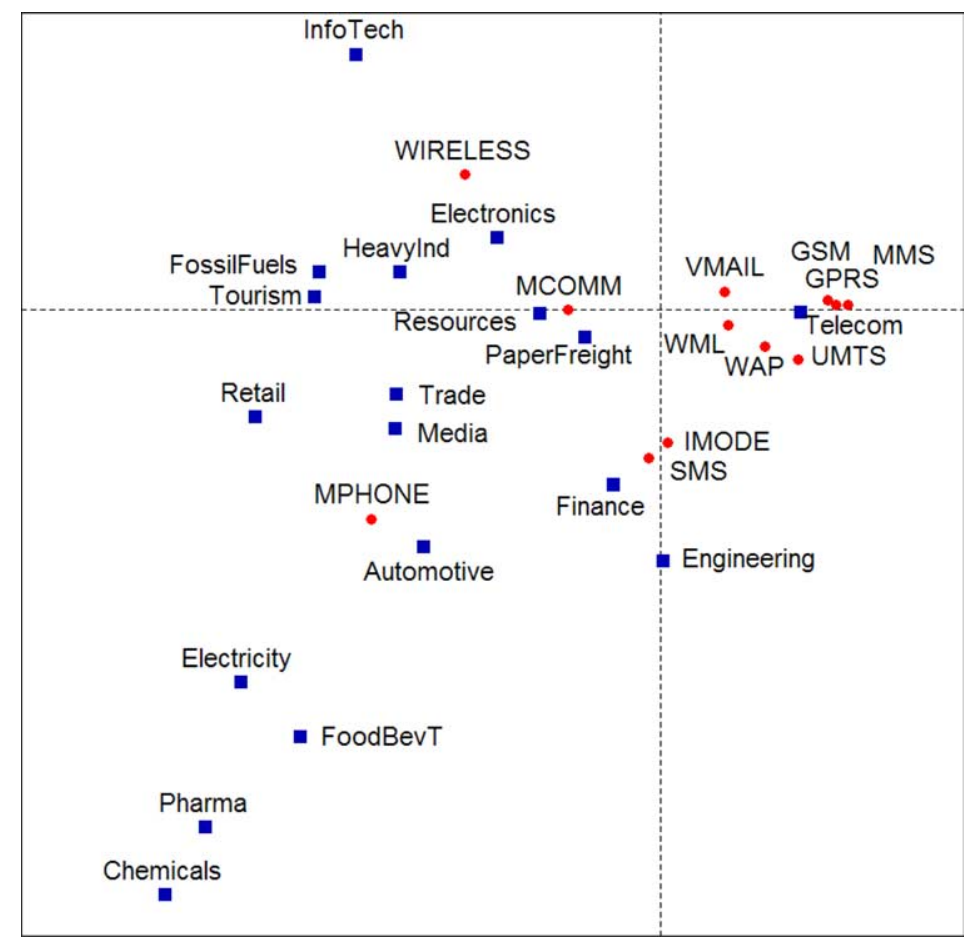

Fig. 4. Perceptual map of mobile marketing terms and Fortune Global 500 industries.

such as traffic reports or weather forecasts - to information the consumer requested [54]. The hybrid nature - information and advertising - of pull advertising blurs the line between advertising and service [55].

Mobile advertising provides consumers with personalized information based on their time of day, location and interests. Consequently, the authors define mobile marketing as using a wireless medium to provide consumers with time- and location-sensitive, personalized information that promotes goods, services and ideas, thereby benefiting all stakeholders.

\subsection{Qualitative research methodology}

Given little research on the adoption of mobile media $[12,13]$ or the socio-economic demographics of adoption [14], the authors used exploratory qualitative research [56,57] to identify relevant variables and relationships. Open-ended questions served as a flexible guideline for interviews [58] with 15 European mobile marketing experts from academia and senior management. Table 1 lists the interviewees' affiliations and positions.

While previous qualitative research analyzed interpersonal SMS communication [59], the interviews focused on SMS marketing. Addressing the study's four research questions and voids mentioned in the literature on consumer behavior, interactive technologies, and technology adoption $[1,2,9,11,52,60-67]$ led to seven interview topics related to SMS advertising: foundations, potential, target groups, message design, success factors, barriers, and trends.

The taped interviews, between 40 and $70 \mathrm{~min}$ each, took place in the interviewees' offices, as qualitative interviews should transpire where the interviewee feels comfortable [56,57]. Two interviewers participated, one leading the interview, the other taking notes. Both interviewers transcribed the taped interviews that day. After transcription, the interviewers coded, categorized and summarized the data for subsequent analysis. 
Table 1

Interviewee groups and their background

\begin{tabular}{ll}
\hline Type of organization & Position \\
\hline Mobile Marketing Companies & Head of Marketing \\
& Team Manager \\
& Business Analyst \\
& Head of Development and Research \\
& Chief Executive Officer \\
Advertising Agencies & Senior Manager \\
& $\begin{array}{l}\text { Person responsible for New Media } \\
\text { Art Director }\end{array}$ \\
Mobile Telephone Companies & Head of Customer Marketing \\
Company Using Mobile Marketing & Head of SMS Advertising \\
Consulting Company & Head of Research \\
Location-Based Services Provider & Consultant and Researcher
\end{tabular}

Universities

Professor, research focus on electronic and mobile commerce Lecturer, research focus on electronic and mobile commerce

Combined with existing literature, this analysis led to the model of effective SMS advertising presented in the following sections.

\subsection{Model characteristics}

Introduced by Daniel in 1961 [68] and originally applied to the evaluation of information systems by Rockart in 1979 [69], the term success factors gained widespread acceptance as the necessary conditions for success in a given market [70]. Nevertheless, many organizations still struggle to define or measure the success of mobile data services. A 2004 Arthur D. Little survey among the senior management of 161 German companies revealed that $27 \%$ were unable to evaluate their success in the mobile data services segment [71]. The model in Fig. 5 suggests relationships between success factors and the success measures of consumer beliefs, intention and behavior. The diagram summarizes the results of the qualitative study and previous research by grouping independent variables of mobile marketing success into two categories, message and media.

The factors in Fig. 5 influence the consumers' attitude towards mobile services, perception of these services and eventual behavior. Davis' work on user acceptance of information technology
[10] and Ajzen's theory of planned behavior $[60,72,73]$ suggest a relationship between the consumer's attitude and the observable behavior. Attitudes, perceived usefulness $[10,74]$ of the mobile service, perceived ease of use (behavioral control), and peer pressure (subjective norms) influence intentions, which are an antecedent of behavior [72]. Hung et al. [15] note the wide-ranging predictive value of these four categories.

Consumer attention, consumer intention and consumer behavior are the conceptual model's measures of SMS marketing success. Attention largely depends on the content of the message. Messages tailored to the interests and preferences of the consumer, for example, can positively affect both attention and consumer attitudes. "Individuals with a persistent interest in a product class... are more likely to pay attention and to expend cognitive effort in processing the message of relevant advertisements" [75, p. 49].

\subsection{Message success factors}

\subsubsection{Content}

Similar to attracting attention in other media, the wording of an SMS advertisement is crucial. A 2001 survey of one thousand mobile phone owners in London identified six types of advertisement: 


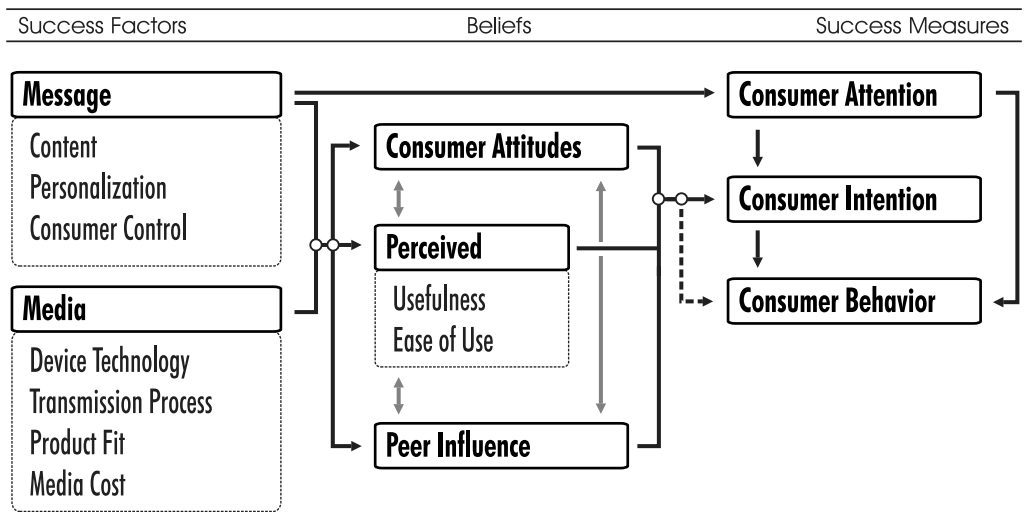

Fig. 5. Model of successful SMS advertising.

brand building, special offers, timely teasers, requests, competitions and polls [9]. Across these categories, the authors found that good text advertisements were short and to the point (28\%), funny and entertaining $(26 \%)$, relevant to the target group $(20 \%)$, eye catching $(13 \%)$, and informative about prizes and promotions $(12 \%)$.

Text messages should contain an attractive idea, convey this idea concisely, employ language understood by the target group, and utilize the available 160 characters effectively [9]. Messages should also disclose on how to stop receiving further messages. When addressing young people, messages should be entertaining and show familiarity with the abbreviations and spitfire conversational style typical of SMS and instant Internet messaging [76].

Advertising funded information services include news, weather, traffic reports, market rates, horoscopes, and details on songs currently played on the radio. Although the receiver pays little or nothing for this information, advertisements must complement consumer interests. Three experts in the qualitative survey emphasized that success depends upon a strong relation between informational needs and the advertisement.

\subsubsection{Personalization}

Marketers can personalize text messages based on the consumer's local time, location, and preferences $[77,78]-$ e.g., directions to the nearest vegetarian restaurant open at the time of request.
Time. Less intrusive than phone calls, recipients can read text messages at their leisure and choose when to respond, if at all [79]. Still, organizations must consider the best time and message frequency for the target group and topic. One interviewee, the CEO of a major mobile marketing company in the German-speaking part of Europe, stressed that "messages should only be sent between 09.00 and 19.30 on weekdays. Addressing students, messages should not be sent before noon, because at this time students can either not be reached efficiently or might get into trouble receiving messages during their classes."

Location. Mobile phones amplify two key arguments for electronic commerce, location independence and ubiquity $[52,78,80]$. Consumers increasingly expect tailored and location-based services, thereby underlining the importance of personalized mobile marketing [77]. Properly applied, location-based services can create or reinforce virtual communities [79]. The Swedish company Telia, for example, one of Europe's biggest and most innovative telecommunication companies, launched a real-time SMS game using mobile positioning to let users play against others in their vicinity (www.botfighters.com).

Preferences. Personalizing messages increases their impact. Similar to traditional media, a personalized SMS campaign relies upon databases with enough active and potential clients to reach the target group profitably. Such databases regularly contain personal information such as leisure 
activities, holidays, music and media interests, type of Internet access, occupation, marital status, car ownership and income [9].

\subsubsection{Consumer control, permission and privacy}

There is a trade-off between personalization and consumer control. Gathering data required for tailoring messages raises privacy concerns. Corporate policies must consider legalities such as electronic signatures, electronic contracts, and conditions for sending SMS messages. Seven experts who had used SMS campaigns welcomed European government and industry initiatives to restrict unsolicited SMS. They argued that sending unsolicited messages hurts the mobile advertising industry.

According to all the experts, advertisers should have permission and convince consumers to "optin" before sending advertisements. A simple registration ensures sending relevant messages to an interested audience [63]. Unsolicited messages, commonly known as spam [81], stifle user acceptance [82] - particularly as mobile phones cannot distinguish between spam and genuine communication automatically. Unwanted messages are illegal in some countries [83] and annoy consumers regardless of the medium (e.g., fax, telephone, electronic mail, or mobile devices). All 15 experts cited fear of spam as the strongest negative influence on consumer attitudes towards SMS advertising.

Changing one's mobile phone number is more difficult than changing e-mail addresses provided by free services such as Yahoo! or Hotmail. New regulations in the United States that allow people to keep their phone numbers when switching cellular carriers [84] may reinforce fears of unwanted messages and misuse of personal data, thereby keeping consumers from registering for SMSbased information services.

\subsection{Media success factors}

\subsubsection{Device technology}

Designing attractive text messages with only 160 characters challenges mobile marketers, but emerging technologies such as GPRS and MMS help overcome this limitation [85]. In Japan, for example, over $90 \%$ of those owning mobile phones with built-in cameras send MMS messages [8]. At the same time, these advances introduce new difficulties. With heterogeneous screen sizes and displays, certain fonts and picture formats look awkward on some mobile devices [86].

Usability issues might also keep consumers from using mobile devices to register for information services. Keying in text messages takes time. Registration via Web forms, by contrast, is easier thanks to a computer's larger keyboard and screen. Consumers may therefore prefer to share their interests, desired content and message preferences via the World Wide Web. A good example of gathering user preferences and permissions via the Web is MindMatics' RedAlertz message service (www.redalertz.co.uk).

\subsubsection{Transmission process}

Seven experts identified two SMS technical barriers. First, a text message may never arrive. Being a "best effort" service, there is no mechanism to ensure successful data transmission. Still, six experts estimated the probability of a text message arriving towards $99 \%$.

Second, there are no guarantees that messages will arrive within a few minutes; delays up to six hours are possible. This is a critical problem for time-sensitive content such as account changes, last-minute tickets, product availability notifications, and weather reports. Instantaneous broadcasts with guaranteed real-time transmission will offer additional opportunities - e.g., notifying travelers of flight status via SMS [87] - and should increase mobile marketing success.

\subsubsection{Product fit}

Its underlying technology positions SMS as appropriate for advertising frequently purchased low-budget items [9]. Nine experts noted that SMS is useful for targeting young audiences - to announce events or support product launches, for example. Twelve of the fifteen experts believe that given the personalized nature of many services, mobile marketing is more useful introducing services than introducing physical goods.

Regardless of the offering, all experts agreed that mobile advertising only succeeds when embedded in the marketing mix. There was no 
agreement among experts, however, about the effectiveness of text messaging for image campaigns. Some argued that transferring the image of a product or company via SMS was possible, while others argued the opposite. Broadband access and advanced mobile devices with multimedia support should increase the medium's attractiveness for image campaigns.

\subsubsection{Media cost}

Cost per thousand or cost per click, traditional advertising measures for established media such as $\mathrm{TV}$, newspapers, radio and the World Wide Web [62], can also gauge mobile marketing's effectiveness. Five interviewees highlighted the importance of calculating a campaign's potential gain against the costs of maintaining customer databases (see prior section on "Personalization").

Mobile marketing can be more cost-effective than other media. The main cost in a text messaging campaign, buying mobile phone numbers, is only necessary if a company fails to convince consumers to "opt-in". According to the interviewed experts, SMS' effectiveness in reaching target groups helps justify the higher price of mobile phone numbers in comparison to e-mail addresses. The response rate of consumers to these mobile campaigns can be almost 20 times higher than with other media $[88,89]$.

\subsection{Consumer behavior}

The experts unanimously claimed that most recipients read the message. Therefore, it is imperative to leverage this consumer attention to influence their behavior. The interviewees argue that, as the impact of messages vanishes quickly, messages usually urge recipients to act on the spot.

\subsubsection{Viral marketing effects}

Rodgers and Thorson [11] provide an extensive summary of responses to online ads, building on Wells' [67] measures of effectiveness in traditional media. A critical measure is attention. Gaining attention, often measured after the fact as recall, is a precondition for influencing consumer action. Compared with other media, the recall rate for mobile advertisements is high [89]. Viral effects
[90] multiply the impact of appealing text messages and consumer attention. By forwarding messages to their friends, recipients create strong peer influence. In their study of WAP (Wireless Application Protocol) services adoption, Hung et al. [15] found that peer influence overshadowed external influences.

For example, an SMS campaign by Wella - a leading European manufacturer of hair cosmetics and fragrances - sent a message "with a kiss" to their SMS opt-in clients. Customers liked the idea and forwarded Wella's kiss to their friends, thereby multiplying the campaign's impact [90]. Wella paid for sending text messages to clients, but paid nothing for messages forwarded to friends [91]. Similarly, Warner Brothers Movie World in Germany invited customers to send a certain message to three friends, who then forwarded the message to Warner Brothers. The first five teams to complete the cycle won free tickets to Warner Brothers' Movie World entertainment park [92]. Viral success, however, is hard to predict since it depends on erratic consumer trends and group dynamics [90].

\subsubsection{Common applications}

Viral effects exemplify transforming attention into action. Other intended consumer reactions to mobile advertising messages include following a link to a Web page, e-mailing the advertiser, purchasing a product, and placing a telephone call [93]. Compared to click-through rates of less than $1 \%$ for Web-based advertising [89], average clickand call-through rates for wireless devices are $19 \%$ and $12 \%$, respectively [89]. Well-targeted campaigns in Japan achieved click-through rates up to $33 \%$ [94].

Mobile couponing. Experts predicted a higher usage of mobile coupons - stored in the mobile phone's memory and therefore difficult to misplace or forget - compared to their paper-based equivalents [95]. Mobile coupons have at least three advantages: targeting based on mobile phone numbers, time sensitivity (e.g., receiving a $20 \%$ discount on purchases upon entering a shop), and efficient handling by scanning the coupon's bar code at the point of sale.

Customer relationship management. Customers can receive free newsletters, pictures, ring tones, 
bonus points or coupons after joining a loyalty program. One expert, a mobile phone operator, plans to send clients SMS information on where to get the cheapest pre-paid phone cards when their credits run low. Sending SMS reminders to clients who fail to pay bills on time is another application popular with the interviewees.

Entertainment services. Half of the experts noted that most people have a natural playfulness and therefore providing games and prizes via text messaging yields high participation and helps attract and keep customers. Research suggests that entertainment applications enhance customer loyalty among the "generation @" - young Internet users between 12 and 16 years old [96]. Television campaigns, such as Big Brother and American Idol where spectators vote for their favorites via SMS [97], as well as the previously mentioned Warner Brothers and Wella campaigns, illustrate SMS entertainment services.

\section{Conclusion}

Acknowledging the complementarities of the World Wide Web and mobile networks, a content analysis of the Fortune Global 500 Web sites investigated the adoption of mobile business models and technologies by region and industry. The results suggest geographic and industry differences in the diffusion of mobile marketing. A perceptual map based on correspondence analysis visualized the importance of mobile technologies by industry, identifying a strong presence not only among technology providers such as telecommunications and electronics companies, but also strong interest for applying mobile services within the automotive and financial sectors.

After developing a broad overview of mobile marketing based on the presence of terms on global Web sites, this paper presented a conceptual model of effective SMS advertising based on a qualitative survey among senior management and academic experts in the field. The model sheds light on nascent forms of mobile advertising. It distinguishes two categories of success factors, message and media characteristics, which influence three dependent success measures: consumer attention, consumer intention and consumer behavior.

The results of these qualitative and quantitative studies give managers insights into current mobile marketing and mobile advertising. These results also indicate future research areas, such as culture. A growing field of research supports that culture influences the adoption of technology [36,37]. For example, could cultural factors help explain Japan's rapid adoption and the lagging deployment of mobile technology in the United States? To explore the role of culture, the language detection algorithm must be extended given Asia's increasing importance in the production [98] and consumption [35] of mobile content.

In addition to longitudinal studies of the Fortune Global 500, further conceptual work is imperative, possibly drawing upon theories in marketing, consumer behavior, psychology, and diffusion of innovation [1,9-11,99]. Future research should investigate emerging standards such as MMS and their impact on planning, executing and evaluating mobile marketing campaigns. Given the ubiquity of mobile devices, what mechanisms determine consumer attention and consumer behavior? User questionnaires and observations of behavioral patterns will help validate the proposed success factors of mobile marketing.

\section{References}

[1] D.L. Hoffman, T.P. Novak, Marketing in hypermedia computer-mediated environments: conceptual foundations, Journal of Marketing 60 (3) (1996) 50-68.

[2] J. Jee, W.-N. Lee, Antecedents and consequences of perceived interactivity: an exploratory study, Journal of Interactive Advertising 3 (1) (2002), Available from: $<$ www.jiad.org/vol3/nol/jee/index.htm>.

[3] TTI, Mobile Messaging: Which Technologies and Applications Will Succeed? (Executive Summary), Telecom Trends International, 2003. Available from: <www. telecomtrends.net/>.

[4] Cellular Online, Latest Mobile, GSM, Global, Handset, Base Station and Regional Cellular Statistivs, 2004. Available from: <www.cellular.co.za/stats/stats-main.htm>.

[5] TTI, Mobile Commerce Has Taken Off, Says Telecom Trends International, Telecom Trends International, 2004. Available from: <www.telecomtrends.net/pr_MIIS-1. htm>. 
[6] M2 Presswire, Arthur D. Little and Exane Report Predicts Continued Revenue Growth for European Mobile Operators, February 18, 2004. Available from: <www.presswire.net/>.

[7] Netsize, The Netsize Guide 2004 - Developing the Multimedia Mobile Market, Paris, 2004. Available from: $<$ www.netsize.com>.

[8] M2 Presswire, Nokia Launches its Latest Research on MMS Usage, May 8, 2003. Available from: <www.presswire.net/>.

[9] P. Barwise, C. Strong, Permission-based mobile advertising, Journal of Interactive Marketing 16 (1) (2002) 14 24.

[10] F.D. Davis, Perceived usefulness, perceived ease of use, and user acceptance of information technology, MIS Quarterly 13 (3) (1989) 319-340.

[11] S. Rodgers, E. Thorson, The interactive advertising model: how users perceive and process online ads, Journal of Interactive Advertising 1 (1) (2000), Available from: $<$ www.jiad.org/vol1/no1/rodgers/>.

[12] B. Anckar, N. Eriksson, Mobility: the basis for value creation in mobile commerce? in: International Conference on Advances in Infrastructure for e-Business, e-Education, e-Science, e-Medicine, and Mobile Technologies on the Internet, L'Aquila, Italy, La Scuola Superiore G. Reiss Romoli, 2003.

[13] Y. Lee, J. Kim, What is the mobile internet for? A crossnational study on the value structure of the mobile internet, in: Americas Conference on Information Systems (AMCIS-2003), Tampa, USA, Association for Information Systems, 2003.

[14] M. Finn, Mobile Commerce on the Eve of 3G, in: Communications Research Forum, Department of Communications, Information Technology and the Arts, Canberra, Australia, 2001.

[15] S.-Y. Hung, C.-Y. Ku, C.-M. Chang, Critical factors of WAP services adoption: an empirical study, Electronic Commerce Research and Applications 2 (1) (2003) 42-60.

[16] Lot21, The Future of Wireless Marketing, Lot21 Emerging Media Group, 2001. Available from: <www.mobilewhitepapers.com/>.

[17] Chordiant, Chordiant 5 Marketing Director Suite, 2003. Available from: <www.chordiant.com/Solutions/ds_ mktdirector4.html>.

[18] W3C, Web Services Activity, World Wide Web Consortium, 2003. Available from: <www.w3.org/2002/ws/>.

[19] Microsoft Corporation and Vodafone Group Services, Mobile Web Services: Convergence of PC and Mobile Applications and Services, 2003. Available from: $<$ www.vodafone.com/assets/files/en/vod1089hr_white_paper. $\mathrm{pdf}>$.

[20] T. Murphy, Assess the Progress of Web Services Adoption, in Windows Server System Magazine. February, 2003. Available from: <www.ftponline.com/wss/>.

[21] D.A. Morf, M.G. Schumacher, S.J. Vitell, A survey of ethics officers in large organizations, Journal of Business Ethics 20 (3) (1999) 265-271.
[22] F. Montenegro-Tores, et al., Are Fortune 100 companies responsive to chronically ill workers?, Health Affairs 20 (4) (2001) 209-219.

[23] D.-W. Lee, C. Blaszczynski, Perspectives of Fortune 500 executives on the competency requirements for accounting graduates, Journal of Education for Business 75 (November/December) (1999) 104-107.

[24] E.E. Lawler III, S. Mohrman, G.E. Ledford Jr., The fortune 1000 and total quality, The Journal for Quality and Participation 15 (5) (1992) 6-10.

[25] V. Gabba, Y. Pan, G.R. Ungson, Timing of entry in international market: an empirical study of U.S. fortune 500 firms in china, Journal of International Business Studies 33 (1) (2002) 39-55.

[26] J.W. Palmer, D.A. Griffith, An emerging model of web site design for marketing, Communications of the ACM 41 (3) (1998) 44-51.

[27] N.C. Romano, Customer relationship management for the web-access challenged: inaccessibility of Fortune 250 business web sites, International Journal of Electronic Commerce 7 (2) (2002) 81-117.

[28] C. Bauer, A. Scharl, Quantitative evaluation of Web site content and structure, Library Computing 19 (3/4) (2000) 134-146.

[29] A. Scharl, Evolutionary Web Development, Springer, London, 2000.

[30] D. Biber, S. Conrad, R. Reppen, Corpus Linguistics Investigating Language Structure and Use, Cambridge University Press, Cambridge, 1998.

[31] T. McEnery, A. Wilson, Corpus Linguistics, Edinburgh University Press, Edinburgh, 1996.

[32] A. Scharl, Web Coverage of Renewable Energy, in: A. Scharl (Ed.), Environmental Online Communication, Springer, London, 2004, pp. 25-34.

[33] D.A. Hull, G. Grefenstette, Querying across languages: a dictionary-based approach to multilingual information retrieval, in: 19th Annual International ACM SIGIR Conference on Research and Development in Information Retrieval, ACM Press, Zurich, Switzerland, 1996.

[34] G. Grefenstette, Comparing two language identification schemes, in: Third International Conference on Statistical Analysis of Textual Data, Rome, Italy, 1995.

[35] Globalreach, Global Internet Statistics (by Language), 2003. Available from: <www.glreach.com/globstats/>.

[36] P. Norris, Digital Divide: Civic Engagement, Information Poverty and the Internet in Democratic Societies, Cambridge University Press, New York, 2001.

[37] D.P. Ford, C.E. Connelly, D.B. Meister, Information systems research and hofstede's culture's consequences: An uneasy and incomplete partnership, IEEE Transactions on Engineering Management 50 (1) (2003) 8-25.

[38] X. Heng, H.T. Hock, H. Wang, Foundations of SMS commerce success: lessons from SMS messaging and coopetition, in: 36th Hawaii International Conference on System Sciences (HICSS-36), Hawaii, USA, IEEE, 2002.

[39] C.H. Marcussen, Comparing SMS and WAP in Europe with i-mode in Japan. Next Generation WAP Services and 
i-mode, IIR Telecoms \& Technology, 2002. Available from: <www.crt.dk/uk/staff/chm/wap/smsimode.pdf>.

[40] M2 Presswire, Research and Markets: Explosive Growth of Text Messaging Throughout Europe, March 3, 2004. Available from: <www.presswire.net/>.

[41] P. Keen, R. Mackintosh, The Freedom Economy: Gaining the M-commerce Edge in the Era of the Wireless Internet, McGraw-Hill Osborne Media, Emeryville, 2001.

[42] J. Davies, Cell-speak Shorthand 'a bg thng' for some clever text messages just beginning to catch on in U.S., SignOnSanDiego, 2001. Available from: <www.pqasb.pqarchiver.com/sandiego/>.

[43] Cellular Online, Adoption of SMS Doubled Among College-Age Users in US, 2003. Available from: $<$ www.cellular.co.za>.

[44] Motorola, Hailing a Singapore Taxi with Satellite Technology, Motorola, 1996. Available from: <www.motorola.com/ies/GPS/docs_html/081596.htm>.

[45] Y. Xu, Development of transport telematics in Europe, in: International Workshop on Geographic Information Systems for Transportation (GIS-T) and Intelligent Transportation Systems (ITS), Hong Kong, 1999.

[46] P. Kannan, A. Chang, A. Whinston, Wireless commerce: marketing issues and possibilities, in: 34th Hawaii International Conference on System Sciences (HICSS-34), Hawaii, USA, IEEE, 2001.

[47] J.-F. Durix, Revolutionising mobile payments, Card Technology Today 15 (10) (2003) 10-11.

[48] Paybox.net, Mobile Payments Delivery Made Simple (White Paper, Version 2.0), 2002. Available from: $<$ www.paybox.net/publicrelations/public_relations_white papers.html>.

[49] C. Johnston, Presentation to the emerging payments technology group, Advanced Card Technology Association of Canada, 2000. Available from: <www.actcda.com/ resource/0006CPA.htm>.

[50] J.F. Hair, et al., Multivariate Data Analysis, fifth ed., Prentice Hall, Upper Saddle River, 1998.

[51] American Marketing Association, AMA Board Approves New Marketing Definition, Marketing News 19(1) (1985) 1.

[52] R.T. Watson, et al., U-Commerce: expanding the universe of marketing, Journal of the Academy of Marketing Science 30 (4) (2002) 333-347.

[53] J.T.-S. Quah, G.L. Lim, Push selling - Multicast messages to wireless devices based on the publish/subscribe model, Electronic Commerce Research and Applications 1 (3-4) (2002) 235-246.

[54] G.A. Schreiber, Schlüsseltechnologie Mobilkommunikation, Deutscher Wirtschaftsdienst, Köln, 2000.

[55] A. Katz-Stone, Wireless revenue: ads can work, australia. internet.com, 2001. Available from: <www.wirelessauthority. com.au/r/article/jsp/sid/445080>.

[56] J.F. Hair, R.P. Busch, D.J. Ortinau, Marketing Research: A Practical Approach for the New Millennium, McGrawHill Higher Education, United States, 2000.
[57] E. Babbie, The Practice of Social Research, 18th ed., Wadsworth Publishing Company, Belmont, 1998.

[58] H.J. Rubin, I.S. Rubin, Qualitative Interviewing, Sage Publications, Thousand Oaks, 1995.

[59] N. Döring, 1 Bread Sausage, Bags of apples I.L.Y. communicative functions of text messages SMS, Zeitschrift für Medienpsychologie 14 (3) (2002) 118-128.

[60] I. Ajzen, The theory of planned behavior, Organizational Behavior and Human Decision Processes 50 (1991) 179211.

[61] P. Kotler, D.C. Jain, S. Maesincee, Marketing Moves, Harvard Business School Press, Boston, 2002.

[62] P. Kotler, Marketing Management, 11th ed., Prentice Hall, Upper Saddle River, 2003.

[63] R.D. Petty, Marketing without consent: consumer choice and costs, privacy, and public poetry, Journal of Public Policy and Marketing 19 (1) (2000) $42-53$.

[64] E.M. Rogers, Communication Technology: The New Media in Society, Free Press, New York, 1986.

[65] E.M. Rogers, Diffusion of Innovations, fourth ed., The Free Press, New York, 1995.

[66] G. Torkzadeh, G. Dhillon, Measuring factors that influence the success of internet commerce, Information Systems Research 13 (2) (2002) 187-204.

[67] W.D. Wells, Measuring Advertising Effectiveness, Lawrence Erlbaum, Mahwah, 1997.

[68] D.R. Daniel, Management information crisis, Harvard Business Review 39 (5) (1961) 111-121.

[69] J.F. Rockart, Chief executives define their own data needs, Harvard Business Review 57 (2) (1979) 81-93.

[70] American Marketing Association, Dictionary of Marketing Terms, 2004. Available from: <www.marketingpower.com/live/mg-dictionary.php $>$.

[71] A. Wilfert, C. Wamser, Mobile Economy 2004 - Development Potential of Mobile Data Services, Arthur D. Little, Duesseldorf, 2004. Available from: <www.adlittle.de>.

[72] I. Ajzen, Perceived behavioral control, self-efficacy, locus of control, and the theory of planned behavior, Journal of Applied Social Psychology 32 (2002) 665683.

[73] I. Ajzen, Nature and operation of attitudes, Annual Review of Psychology 52 (2001) 27-58.

[74] M. Koufaris, Applying the technology acceptance model and flow theory to online consumer behavior, Information Systems Research 13 (2) (2002) 205-223.

[75] F. Kokkinaki, P. Lunt, The effect of advertising message involvement on brand attitude accessibility, Journal of Economic Psychology 20 (1) (1999) 41-51.

[76] J. Lee, I Think, Therefore IM, in New York Times (September 19), 2002. Available from: <www.nytimes.com/>.

[77] R.T. Watson, et al., Electronic Commerce: The Strategic Perspective, Dryden, Fort Worth, TX, 2000.

[78] S. Balasubramanian, R.A. Peterson, S.L. Jarvenpaa, Exploring the implications of M-Commerce for markets and marketing, Journal of the Academy of Marketing Science 30 (4) (2002) 348-361. 
[79] H. Geser, Towards a sociological theory of the mobile phone. Available from: <www.socio.ch/mobile/t_geser1.htm>.

[80] B. Anchar, D. D'Incau, Value-added services in mobile commerce: an analytical framework and empirical findings from a National Consumer Survey, in: 35th Hawaii International Conference on System Sciences, Hawaii, USA, IEEE, 2002.

[81] S. Hinde, Spam: the evolution of a nuisance, Computers and Security 22 (6) (2003) 474-478.

[82] Golem. de, Mobiles Marketing ist noch ein Wunschtraum, 2002. Available from: <www.golem.de/0108/15375.html>.

[83] A. Stratil, E.-M. Weissenburger, Telekommunikationsgesetz, Manz, Vienna, 2002.

[84] CNN, New Switching Rules May Trash Millions of Cell Phones, Cable Network News (October 31), 2003. Available from: <www.edition.cnn.com/2003/TECH/ptech/10/ 31/sprj.ws.cellphone.garbage.ap/>.

[85] OMA, Multimedia Messaging Service - Architecture Overview Version 1.1, Open Mobile Alliance, 2002. Available from: <www.openmobilealliance.org/documents. asp>.

[86] H.M. Yunos, J.Z. Gao, S. Shim, Wireless advertising's challenges and opportunities, IEEE Computer 36 (5) (2003) 30-37.

[87] F. Newell, K.N. Lemon, Wireless Rules - New Marketing Strategies for Customer Relationship Management, McGraw-Hill, New York, 2001.

[88] Quios/Engage, The Efficacy of Wireless Advertising: Industry Overview and Case Study, 2000. Available from: <www.mobilecommerceworld.com/download/Quios Engage_WP.pdf $>$.

[89] Windwire, First-to-Wireless: Capabilities and Benefits of Wireless Marketing and Advertising Based on the First National Mobile Marketing Trial, 2000. Available from:
$<$ www.imapproject.org/imapproject/downloadroot/public3 /ftw_report.pdf>.

[90] S. Godin, Unleashing the Idea Virus, Hyperion, New York, 2001.

[91] Snap, Mobile-Marketing Aktion für Wella Design erfolgreich: 55.000 Mobile Küsse, Press Release (Dec 7), 2001. Available from: <www.12snap.com/uk/press>.

[92] MindMatics, MindMatics setzt erfolgreiche SMS Kampagne für Coca-Cola und Warner Brothers Movie World um, Press Release (December 6), 2001. Available from: $<$ www.mindmatics.com/>.

[93] S.J. Barnes, Wireless digital advertising: nature and implications, International Journal of Advertising 21 (2002) $399-420$

[94] T. Natsuno, The i-mode Wireless Ecosystem, Wiley, Yokohama, 2003.

[95] M. Raskino, Mobile coupons will reach right into your pocket, GartnerGroup Research Note (July 16) (2001), Available from: <www.gartner.com/>.

[96] J. Hartmann, R. Büppelmann, Siemens End-User Survey Europe, Siemens AG, Munich, 2001.

[97] H. Nysveen, P.E. Pedersen, H. Thorbjornsen, Using mobile services to strengthen brand relationships: the effects of SMS and MMS channel additions on brand knowledge, satisfaction, loyalty and main channel use, SNF-Report No: 22/03, 2003, p. 131.

[98] E.T. O’Neill, B.F. Lavoie, R. Bennett, Trends in the evolution of the public web, D-Lib Magazine 9 (4) (2003), Available from: <www.dlib.org/dlib/april03/lavoie/ 04lavoie.html> .

[99] P. Barwise, A. Elberse, K. Hammond, Marketing and the Internet: A Research Review, London Business School, London, 2002, Available from: <www.marketingandthein ternet.com/>. 